\title{
Visualization of the territorial origins of the inhabitants of the Recovered Territories (Poland) in 1950
}

\begin{abstract}
This paper gives a visualization of the territorial origins of the population of the Recovered Lands (Poland) in 1950. It constitutes a map series, based on Kosiński's research from 1960, presenting data from the first post-war census. Vector data of the historical administrative borders of Poland was used to prepare the maps; specifically the administrative division of the People's Republic of Poland from 1946 and the state border of the Second Republic of Poland from 1931. The administrative borders were modified as appropriate using, among other things, historical maps and satellite images. The results of this research constitute a comprehensive study on the origins of the population of the Recovered Territories. Twenty-four maps were designed, showing many aspects of the studied phenomenon.
\end{abstract}

Keywords

Recovered Territories $\cdot$ resettlement $\bullet$ migration $\bullet$ the origins of the population • visualization

(C) University of Warsaw - Faculty of Geography and Regional Studies

\author{
Szczepan Cegiełko $\mathbb{C}^{1}$, Izabela Karsznia $\mathbb{C}^{1}$ \\ 'Department of Geoinformatics, Cartography and Remote \\ Sensing, Faculty of Geography and Regional Studies, \\ University of Warsaw, Warsaw, Poland \\ e-mail: s.cegielko@gmail.com \\ e-mail: i.karsznia@uw.edu.pl \\ Received: 12 May 2020 \\ Accepted: 26 June 2020
}

\section{Introduction}

The aim of this study was to visualize the origins of the population of the Recovered Territories. The data on the origins of the population was acquired from Kosiński's research (Kosiński 1960). The scope of this study covered the development of a set of maps:

- fourteen maps showing the percentage of the population that originated from fourteen provinces located in the area of the Former Lands, related to the total population of a given county;

- one map showing the percentage of the indigenous population, related to the total population of a given county;

- one map showing the percentage of the incoming population, related to the total population of a given county;

- one map showing the percentage of the population of unknown origin, related to the total population of a given county;

- one map showing the percentage of the population that came from the USSR, related to the total population of a given county;

- one map showing the percentage of the population that came from other countries, related to the total population of a given county;

- one map showing the population of the Recovered Territories according to their mixing degree;

- one map showing the origins of the dominant population group in a given county;

- two maps showing the number of immigrants and displaced persons to the Recovered Lands, for each province of the Former Lands;

- a map which provides a legend for all the other maps (an administrative division of the Recovered Territories).
The area under study covered the aforementioned Recovered Lands - the territories granted to Poland during the Potsdam Conference and the territory of the former Free City of Gdansk (Marcinek 1996). The Former Lands comprise the parts of the Polish People's Republic ${ }^{1}$ that were located in pre-war Poland (today's eastern and central Poland). One of the standard tools used for visualizing changes is the study of migration and resettlement. This phenomenon is particularly relevant to the 20thcentury history of Poland. Some of the largest forced relocations of people in the world took place during the Second World War and in the immediate post-war years. The largest resettlements occurred just after the Second World War. This period mainly concerns two, large, opposing migratory movements. In the years 1946-49, approximately 2.3 million Germans and 176,000 Belarussians, Lithuanians and Ukrainians were resettled outside Poland's borders (Kosiński \& Dziewoński 1967). The second great movement was the settlement of the Recovered Lands. These lands were settled by Polish people who came from the eastern parts of pre-war Poland (Eastern Borderlands of pre-war Poland ${ }^{2}$ ), from the USSR (about 666,000 people in total) and from western countries (about 823,000 people). This movement applies to the resettlement from the Former Lands to the Recovered Territories and also applies to "Operation Vistula", which was the pacification and resettlement action for Ukrainians, Lemkos, Boykos and Dolinians in connection with the terrorist activities of the OUNUPA organization (Konieczny 2002). There was also much migration from villages to cities.

\footnotetext{
${ }^{1}$ PL: PRL Polska Republika Ludowa (Polish People's Republic)

${ }^{2} \mathrm{PL}$ : Kresy Wschodnie (Eastern Borderlands)
} 


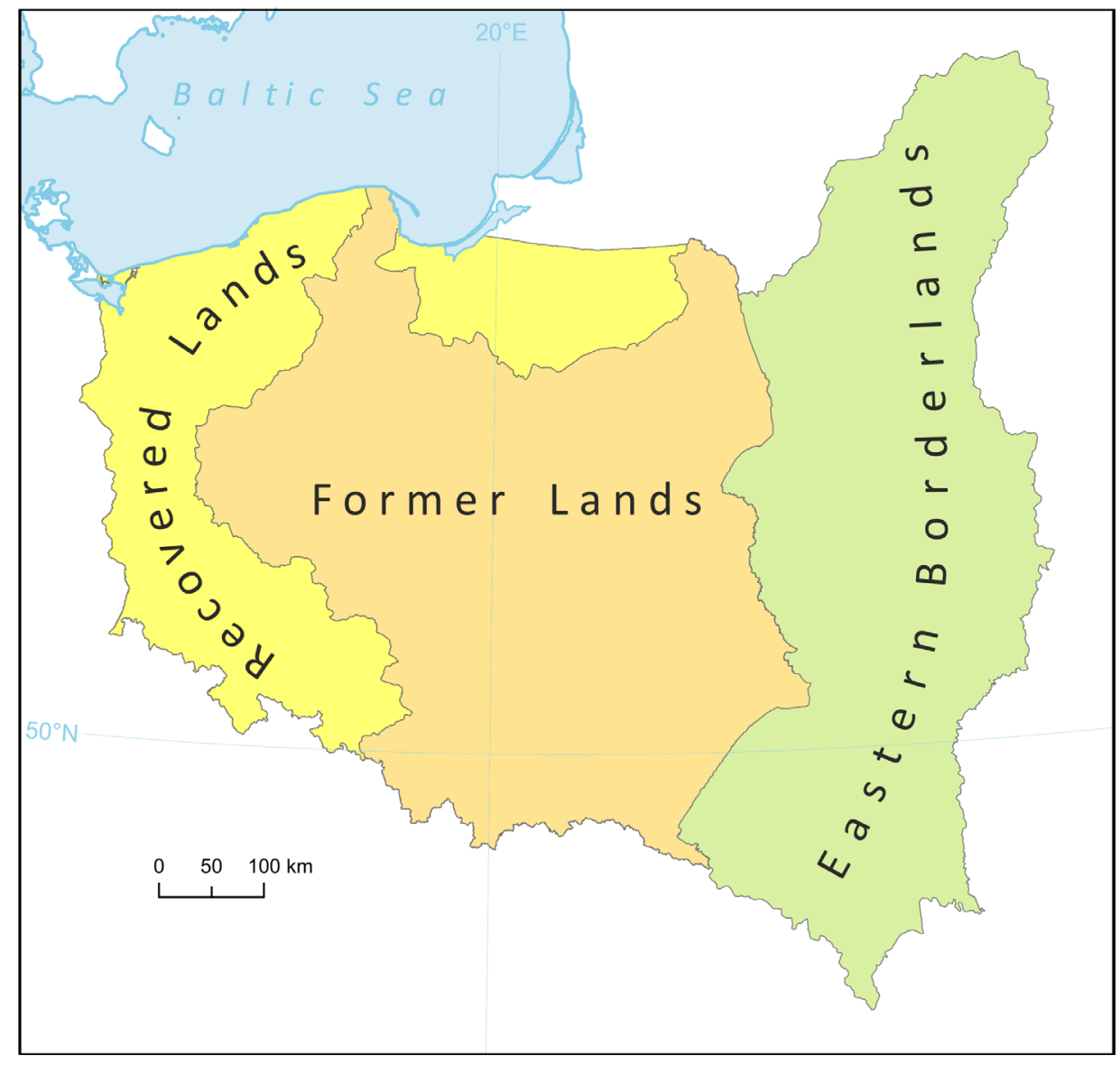

Figure 1. Research area. Source: own elaboration

\section{Related works}

Presentation of dynamic phenomena on maps

The dynamics of phenomena presented on maps are divided into the dynamics of movement (location dynamics) and the dynamics of state (development dynamics). The dynamics of movement concern only the changes in the location of an object in space, e.g. the migration of a large group of people. The dynamics of state refer to changes that are not related to change of location in space, but to changes in the quantitative and qualitative characteristics of objects (Meksuła 2002), e.g. changing population levels. There is also a third type of complex dynamics, which is a combination of state and movement dynamics (Meksuła 2001).

According to Meksuła (2002), cartographic representations of the dynamics of phenomena can be divided into indirect (i.e. static) maps, and direct, (i.e. dynamic) maps. Static maps are maps on which the dynamics of movement and state are shown in a static way. We distinguish between a series of maps and single maps. A map series is a set of several maps concerning a given phenomenon, presenting the data at specific time intervals. These are particularly popular for visualizing the transformation and evolution of the natural environment (Saliszczew 1984). A series of maps typically includes comparative maps, overlay maps, and two-sided maps.

The second group of static maps which present the dynamics of phenomena are single maps, which include multiphase maps, balance sheet maps, and type maps. A multi-phase map is a specific type of overlay map, which is created by superimposing an overlay map on the basemap (Meksuła 2002; Kałamucki \& Buk 2010). Multi-phase maps, unlike map series, allow measurements to be taken. They also allow the use of many different methods of presenting both the dynamics of movement and the dynamics of state. However, they are more limited in their ability to show the complexity of the dynamics of the phenomena.

Balance sheet maps (also called indicator maps) present an indicator that shows the effect of a change in the phenomenon over time (state dynamics). They usually represent the difference between the values of a given phenomenon between two points in time (Meksuła 2001 after Freitag 1966), e.g. the migration balance. In other words, balance sheet maps show the effect of a given phenomenon, not its values at specific points in time.

The third type of single map is the type map, i.e. a map of changes showing the variability of different types of phenomenon. This can cover elements such as stagnation, rise and fall, intensity, continuity and the nature of the occurrence of a phenomenon over the analysed time profile (Meksuła 2001). Type maps allow one to show changes which are complicated and difficult to distinguish.

Animated maps are the final form of presentation of phenomena dynamics. In this case, both the dynamics (motion and status) are shown directly. This means that the viewer can see the change and follow it. Animated maps are the answer to the need for the direct visualisation of time (Harrower and Fabrikant 2008). Animated maps include cartographic films and computer animations. There are many methods of presenting phenomena dynamics on the above-mentioned maps. Their selection depends on the specificity of the objects and phenomena presented on 
the map (Kałamucki \& Buk 2010). The classification of cartographic methods of presentation of phenomena dynamics was proposed, among other people, by Ostrowski (1984). The methods related to movement dynamics include linear symbols (arrows), vector diagrams and isochrones. In contrast, the methods related to the dynamics of state include a dynamic comparison diagram, a dynamic choropleth map and isodates (Ostrowski 1984). Other authors also include flow maps as methods for showing the variability of the phenomenon (Ratajaski 1989; Meksuła 2002). These are particularly popular in the visualisation of phenomena such as migration (Guo 2009).

Visualizations of post-war migration and population resettlement in Poland

Post-war migration and resettlement have been a frequent subject of visualization - both in historical atlases and in Internet cartography. Due to the specificity of the phenomenon of mass migration, the dominant form of cartographic presentation is with static multi-phase maps. The most commonly-used methods include arrow symbols and forms which are a combination of arrow symbols and flow maps (arrows whose width depends on the size of the migration). Examples of the use of diagram methods and arrow symbols in maps about post-war resettlement can be found in the works of Eberhardt (Eberhardt 2011).

The maps concerning the origins of the population of the Recovered Territories have so far been static maps, showing the origins of the population by province (voivodeship). The most common method of cartographic presentation was to use structural diagrams and choropleth maps with a low degree of detail, usually broken down by province. A much more detailed document is The Origin of the Population of Western Lands in 1950 (Kosiński 1960). This shows the origins of the population of the Recovered Territories within counties, in the form of maps (Kosiński 1960). Based on the data published in the research, Kosiński also developed a map of the territorial origin of the population of the Recovered Territories. When designing the map, he took into account only three main population groups the indigenous population, immigrants from other countries, and immigrants from the Former Lands. This map was published in the Atlas of the Republic of Poland and was co-authored by Gawryszewski (Gawryszewski \& Kosiński 1993-1997). The census data on which Kosiński's works were based have not yet been fully utilised to visualize the origins of the population of the Recovered Territories. This research aims to fill this gap.

\section{Source Data}

The main data source is "The Origin of the Population of Western Lands in 1950". This is research which was prepared by L. Kosiński, published by the Institute of Geography of the Polish Academy of Sciences, in 1960, in Warsaw. The research paper describes in detail the population of the Recovered Territories. In the title of the publication, the author uses the phrase "Western Lands" which refers to the Recovered Lands. The publication is based upon data collected as part of the National Census conducted in December 1950 (GUS PRL 1955). This information was further filled out with data made available by Statistics Poland (SP) in the years 1957-1958. Among other things, a question was asked about place of residence in 1939. The answers to this question provided information on the volume of migration and on the origins of the inhabitants of particular parts of the Recovered Lands. Before Kosiński's research was developed, the publications on the origin of the population of the Recovered Territories was less detailed or had an uncertain statistical basis (Kosiński 1960). Thanks to the availability of the statistical data provided by SP to the Institute of Geography, it was possible to develop more detailed analyses of the origins of the population. The data was presented at county level. Kosiński prepared tables of the origins of the population from the Recovered Territories and characterized the distribution of particular population groups. The work includes sixteen maps:

- the indigenous population as a percentage of the total population in 1950,

- population inflow from the USSR as a percentage of inflow population in 1950,

- foreign inflow population (without the USSR) as a percentage of inflow population in 1950 ,

- eleven maps covering inflow population from 11 provinces of the People's Republic of Poland, whose territory was part of the Second Republic of Poland, expressed as a percentage of inflow population in 1950,

- the population of the Western Lands by territorial origin in 1950 ,

- $\quad$ the population of the Western Lands by the degree of mixing.

Other source data used in this study is vector data relating to the administrative division of the Polish People's Republic from 1946. This constituted the basis for building the main layer for each of the maps. The data was acquired from the "Ontological Basis of Building Historical Geographical Information Systems" project, financed by the National Humanities Development Programme ${ }^{3}$. This project was conducted in the Tadeusz Manteuffel Institute of History of the Polish Academy of Sciences. Within the project scope, the county boundaries were vectorized from the administrative map published by the Military Geographic Institute $\left(\mathrm{MIG}^{4}\right)$, at a scale of 1:1,000,000, from 1947. The work also uses vector data available on the Mosaic project portal ${ }^{5}$, namely the border of the Second Polish Republic from 1931. This data was used for all elaborated maps.

Apart from vector data, raster data(i.e. old maps) were also used. Three of these are maps showing the administrative division of the People's Republic of Poland, developed and published by MIG, in 1946, 1947 and 1948, at a scale of 1:1,000,000. Within this research a scan of the administrative map prepared by the State Cartographic Publishing Company and published in 1957 was also used. Additionally, two scans of general geographic maps of Poland, published by MIG in 1947, at a scale of 1:500,000 (the sheets of Wałbrzych and Szczecin) were used. The physical map of the Second Republic of Poland, published in 1932 by Eugeniusz Romer at the Institute of Geography, at a scale of 1:1,250,000, also constituted a source of data. Apart from this, the base map "World Imagery" available in the ArcMap 10.5 programme was also used. The legal acts of the People's Republic of Poland from 1946-1951 were used to modify the administrative division of vector data referring to 1946 . These legal acts constitute three regulations of the Council of Ministers $\left(29.05 .1946^{6}, 21.06 .1950^{7}, 14.12 .1950^{8}\right)$, the Act of $28.06 .1950^{9}$ and the Decree of $06 \cdot 10.1948^{10}$.

\section{Research methodology}

The research methodology consisted of several stages: an initial assessment of the accuracy of the input data,

${ }^{3}$ ONTOHGIS ontological foundations for building historical geoinformation system

${ }^{4} \mathrm{PL}$ : Wojskowy Instytut Geograficzny (Military Geographic Institute)

${ }^{5}$ ONTOHGIS ontological foundations for building historical geoinformation system, Mozaic

${ }^{6}$ Rozporządzenie Rady Ministrów z dnia 29 maja 1946 r. (Regulation of the Council of Ministers of 29 May 1946)

${ }^{7}$ Rozporządzenie Rady Ministrów z dnia 21 czerwca 1950 r. (Regulation of the Council of Ministers of 21 June 1950)

${ }^{8}$ Rozporządzenie Rady Ministrów z dnia 21 czerwca 1950 r. (Regulation of the Council of Ministers of 21 June 1950)

${ }^{9}$ Ustawa z dnia 28 czerwca 1950 r. (the act of 28 June 1950)

${ }^{10}$ Dekret z dnia 6 października 1948 r. (decree of 6 October 1948.) 


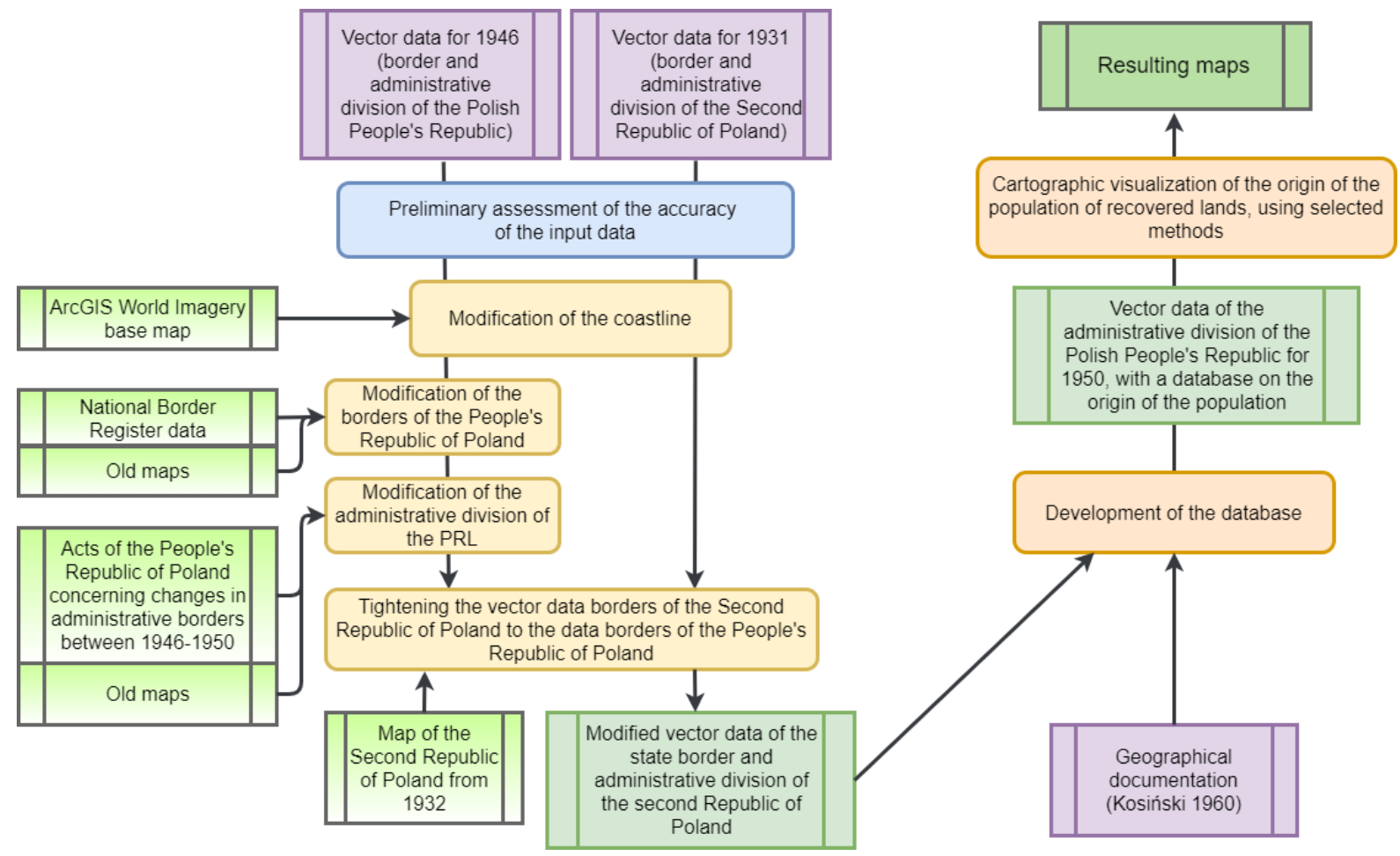

Figure 2. Diagram of the research methodology (own elaboration)

modification of the vector data, database design and verification of its accuracy. The last stage of the methodology was the cartographic visualization of the origin of the population of the Recovered Territories using selected cartographic presentation methods (Figure 2). All research stages were conducted in ArcMap software, version 10.5. The auxiliary program for map editing was CorelDRAW.

The initial evaluation of vector data quality was based on the identification of errors in the database and inaccuracies in administrative borderlines. In the case of vector data of the administrative division from 1946, the main problems were the inaccuracy of the coastline and the presence of Polish administrative units reaching beyond the Polish-German border. Another problem was the incompleteness of the vector database (lack of names assigned to some administrative units). Moreover, the vector data was not matched with the vector data relating to 1931 (a mismatch between the coastline and the southern border based on the Carpathian Mountains). The course of the coastline of both layers was modified on the basis of the "World Imagery" basemap available in ArcMap 10.5. The next stage of research was to modify the borders of the former Polish People's Republic (vector data referring to 1946). The state borders with Czechoslovakia near Harrahov and the German-Polish border, near Świnoujście on the Uznam island, were modified. The modification was carried out on the basis of archival MIG maps. Some counties bordering on the German Democratic Republic were erroneously "sticking out" beyond the border of the People's Republic of Poland. These borders were adjusted to the vector data of the State Borders' Register. The next stage was to modify the administrative division of the Polish People's Republic. This consisted of removing areas not assigned to any counties and introducing administrative changes ordered by the authorities of the People's Republic of Poland in the years 1946-1951. These modifications covered the creation of new counties and provinces and changes in their names. The modification was carried out on the basis of archival maps from 1946-1957 and legal acts of the Polish People's Republic. The next stage was to make the vector data, namely the borders of the Second Polish Republic, consistent with the borders of the People's Republic of Poland. This covered the consistency of land borders common to both layers: the southern border, based on the Carpathians Mountains and the eastern border near the Suwałki region.

The last stage was to design the database, based on information from Kosiński's research. This consisted of assigning twenty-four attributes to each administrative unit of the People's Republic of Poland located in the area of the Recovered Territories. Sixteen of these concerned the percentage of the population originating from a given area. The remaining eight attributes constituted the name of the county; the name of the province in which the county is located; the county's population; the share of people of undetermined origin in the total population of the county; the share of indigenous people in the total population of the county; the share of incoming people in the total population of the county; a category for the degree of population mixing and a code symbolizing the dominant population group in the county. In the analysed research the share of the population coming from a given area refers only to the inflow population of a given county. In order to obtain the percentage share of origin for the total population of the counties of the Recovered Territories the values in each county were calculated. As a result, the percentage of the population coming from a given place has decreased. The smaller the percentage of inflow population in a given county, the more it has decreased. A separate database has been created for provinces located in the Former Lands. This shows the number of people who emigrated to the Recovered Territories per each province of the Former Lands. Of eleven attributes relating to the Former Territories, ten referred to the number of people who emigrated to the Recovered Territories (as migration and resettlement targets), while one represented the total number of migrants and displaced persons from a given region. 

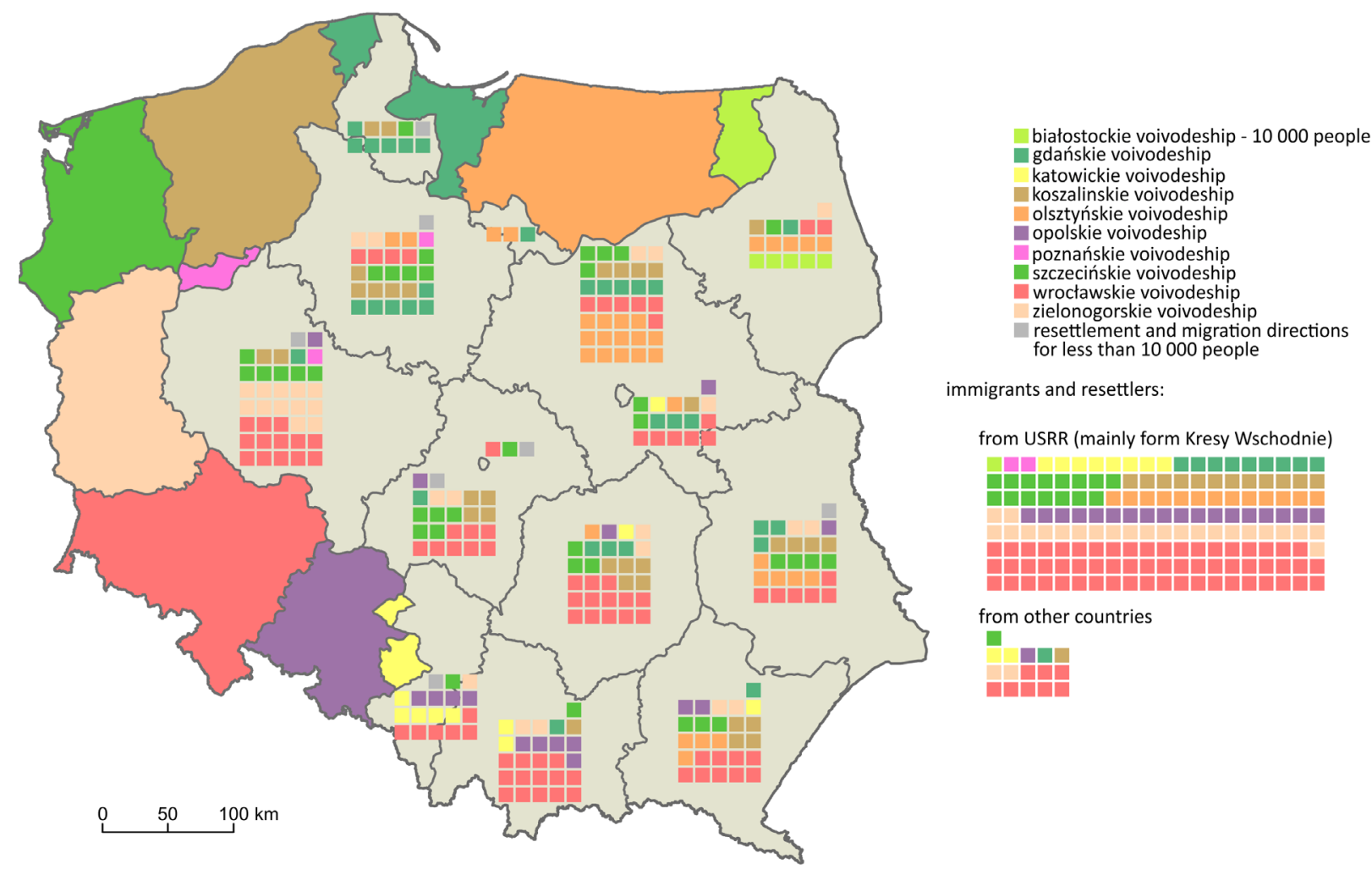

immigrants and resettlers:

from USRR (mainly form Kresy Wschodnie)

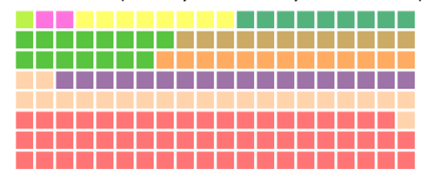

from other countries

-

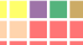

Figure 3. Immigrants and forced re-settlers to the Recovered Lands from particular areas of former Poland according to the 1950 census Source: Author's map based on Kosiński 1960

Results

The results of this research were the development of twentyfour maps relating to the Recovered Territories:

- fourteen maps showing the percentage of the population that came from fourteen provinces located in the area of the Former Lands (the provinces of Bydgoszcz, Gdańsk, Poznań, Białystok, Katowice, Kielce, Kraków, Lublin, Łódź, Olsztyn, Rzeszów and Warsaw, as well as the city of Warsaw and the city of Łódź), related to the total population of the given county;

- two similar maps - one showing the percentage of the indigenous population and the other showing the percentage of inflow population, related to the total population of a given county;

- a map showing the percentage of the population of unknown origin, related to the total population of a given county;

- a map showing the percentage of the population coming from the USSR, related to the total population of a given county;

- a map showing the percentage of the population coming from other countries (excluding the USSR), related to the total population of a given county;

- a map showing the population of the Recovered Territories according to their degree of mixing;

- a map showing the origin of the dominant population group in the county;

- two maps showing the number of immigrants and displaced persons to the Recovered Territories, by province of the Former Lands:

- a map which provides a legend for all the designed maps (an administrative division of the Recovered Territories).
The maps were designed in the form of single static maps, showing the dynamics of state. Most of the developed maps also have features of balance maps, showing the effect of a given phenomenon. All maps, except the last one, are designed at a scale of $1: 4,000,000$. The last map presents the administrative division of the Recovered Territories and constitutes a legend for all the other maps. This map has been developed to allow easy reading of the names of the counties of the Recovered Territories. The map was designed at a scale of 1:2,500,000. Of the twentythree remaining maps, twenty-one used the choropleth method as the main method, which shows the inclusion of a given county within a certain percentage range of the examined population group's share in the total county population. In each case, different class intervals were used, depending on the range of the phenomenon's values. The class intervals have been assumed to be right-closed. When delimiting the class intervals, care was taken to ensure that they were as large as possible and to ensure that the limit values of the class ranges are divisible by 10,5 or 2.5; depending on the range of the phenomenon. If the percentage of a given population group was more than $50 \%$, this value was the extreme value of the range. This allows one to determine which county has an absolute majority of a given population group. Each of the choropleth maps uses a single-tone convergent colour scale. The darker the hue of a given colour, the higher the percentage of a given population group in the county's total population. In the remaining two maps - showing immigrants and displaced persons to the Recovered Territories for each province of the Former Lands - the diagram method was used. The first of these maps uses a segment diagram. Each Province of the Former Lands was assigned square segments, symbolizing ten thousand people who emigrated or were forcibly resettled in the 


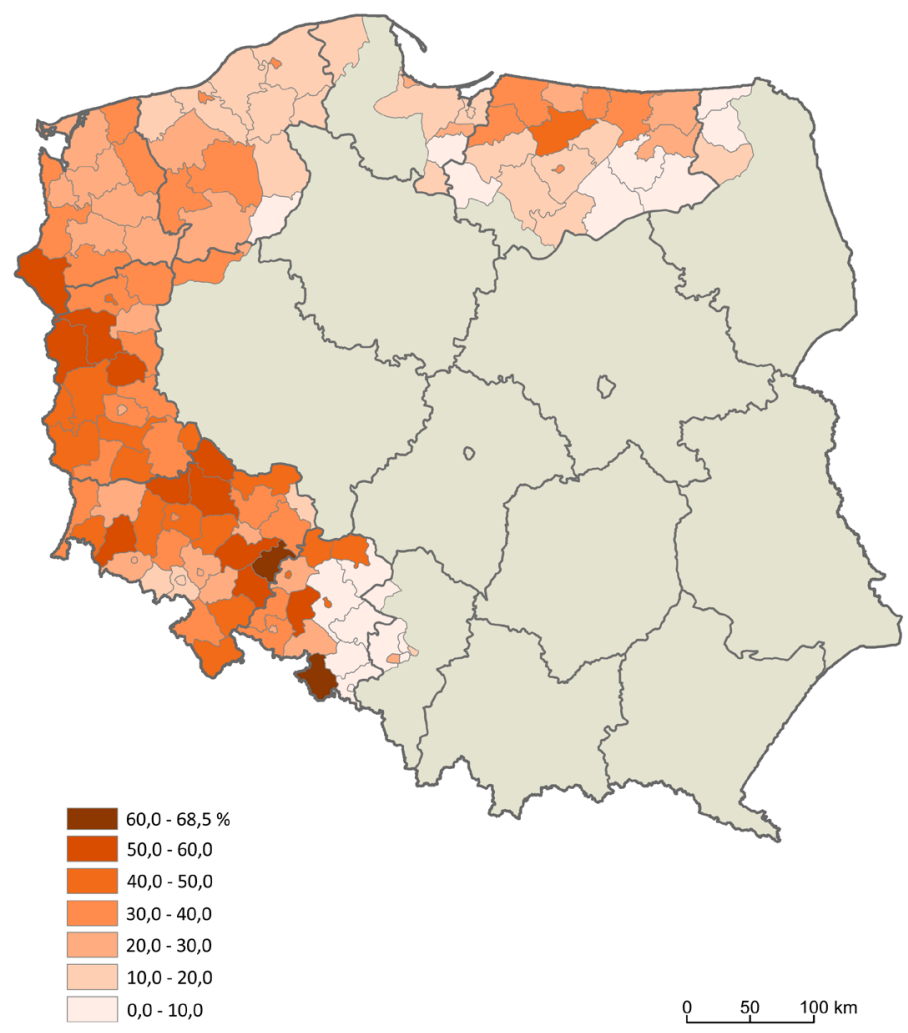

Figure 4. Population from the USSR (mainly from the Eastern Borderlands of pre-war Poland) in the Recovered Territories in 1950 Source: Author's map based on Kosiński 1960

years preceding 1950. In the second map, a summary-structural diagram map was used. The larger the area of the circle, the greater the number of people who left the given province of the Former Lands. The percentage share of each of the regions of the Recovered Territories is reflected in a section of a circle with a given angle.

\section{Discussion \& Conclusions}

The resulting maps should be compared with existing studies, both with Internet cartography and atlas maps such as the Atlas of the Republic of Poland (Gawryszewski \& Kosiński 19931997). The two most important criteria for evaluating the resulting maps are the degree of detail and the accuracy of the vector data. The level of detail of the designed maps is the same as the level of detail of the maps from Kosiński's research and the map from the Atlas of the Republic of Poland. The maps show the Recovered Lands by county, which is the most detailed division, taking into account the availability of statistical data. The resulting maps, therefore, show the social structure of the Recovered Territories in more detail than most studies so far. A more difficult comparison criterion is the accuracy of the vector data. The vector data used for the development of the maps was modified repeatedly and verified using both numerous raster data (old maps, referring to the period 1932-1957) and satellite images ("World Imagery" basemap). In addition, the results of the modification of this data were verified by comparing them to the legal acts of the People's Republic of Poland (PRL) from 1946-1951. Therefore, it can be stated that the accuracy of the developed maps is at least no worse than the accuracy of previous ones.

Another very important criterion for the evaluation of the research results is their informative richness and comprehensiveness. The maps show the percentage of the population coming from sixteen areas of origin (fourteen provinces of the Former Lands, the USSR, and other countries) and the percentage of the incoming and indigenous populations. This is the most synthetic study that has been prepared so far. Even Kosiński's maps, attached to his research, show only the origins of thirteen areas (among other places, the provinces of the Former Lands, while Olsztyn province and cities with provincial rights were not included). Other cartographic studies take into account groups of provinces or a very generalised division of the population into indigenous people, people displaced from the Eastern Borderlands of pre-war Poland, and people displaced from the Former Lands. The maps designed within this study into population origin differ significantly from Kosiński's maps, as the percentage of a given population group is related to the total population of a given county, not to the total inflow population. This makes it easier to assess the diversity of population origin. Moreover, the resulting maps show the dominant population group in each county (Figure 7) as well as the population according to the degree of mixing, which so far has only been sketched in Kosiński's research. Three other maps were also developed; a map of population of unknown origin, and two maps showing immigrants and forcibly displaced people to the Recovered Territories from particular areas of former Poland. In the case of the first map, the detail is at county level, while, in the next two maps, at the provincial level (Figure 3). These maps have never been developed in such detail before.

To sum up, the greatest advantages of the developed maps include a high level of informativeness, high comprehensiveness of the study, uniqueness (development of data, not visualized so far), and high data accuracy, as well as high map readability. This 


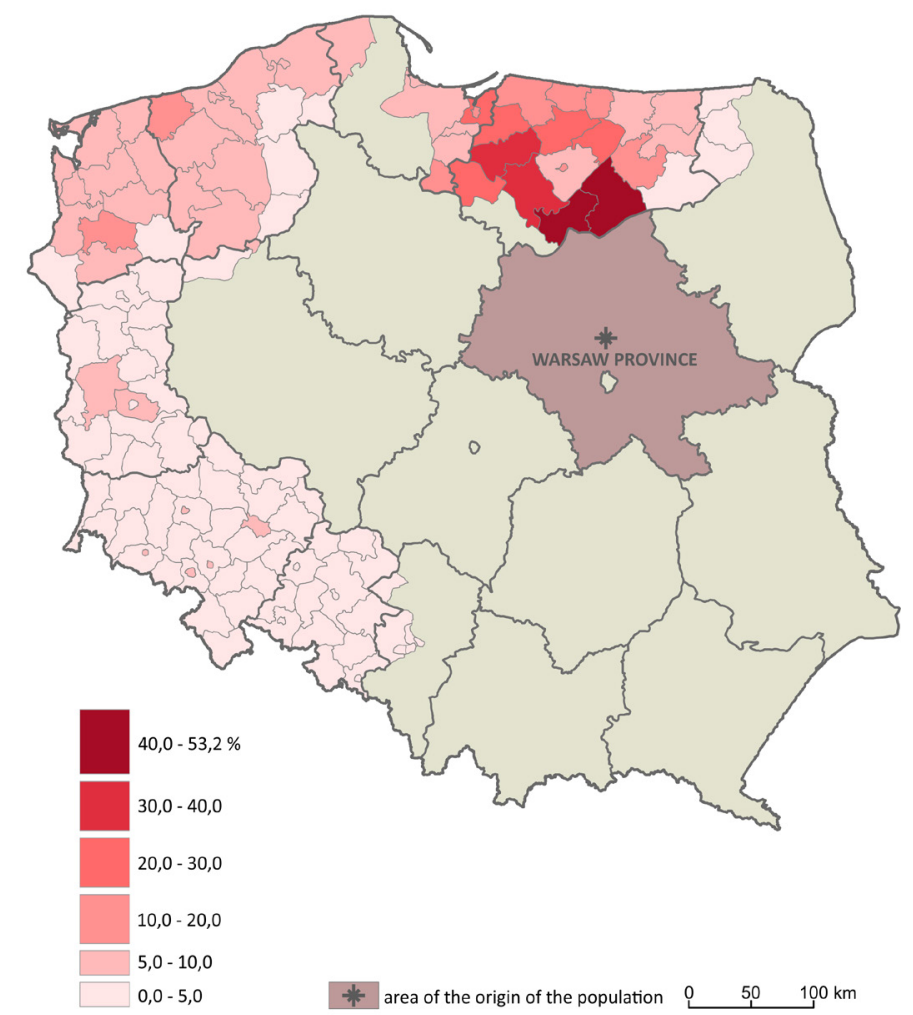

Figure 5. Population from Warsaw Province in the Recovered Territories in 1950 Source: Author's map based on Kosiński 1960

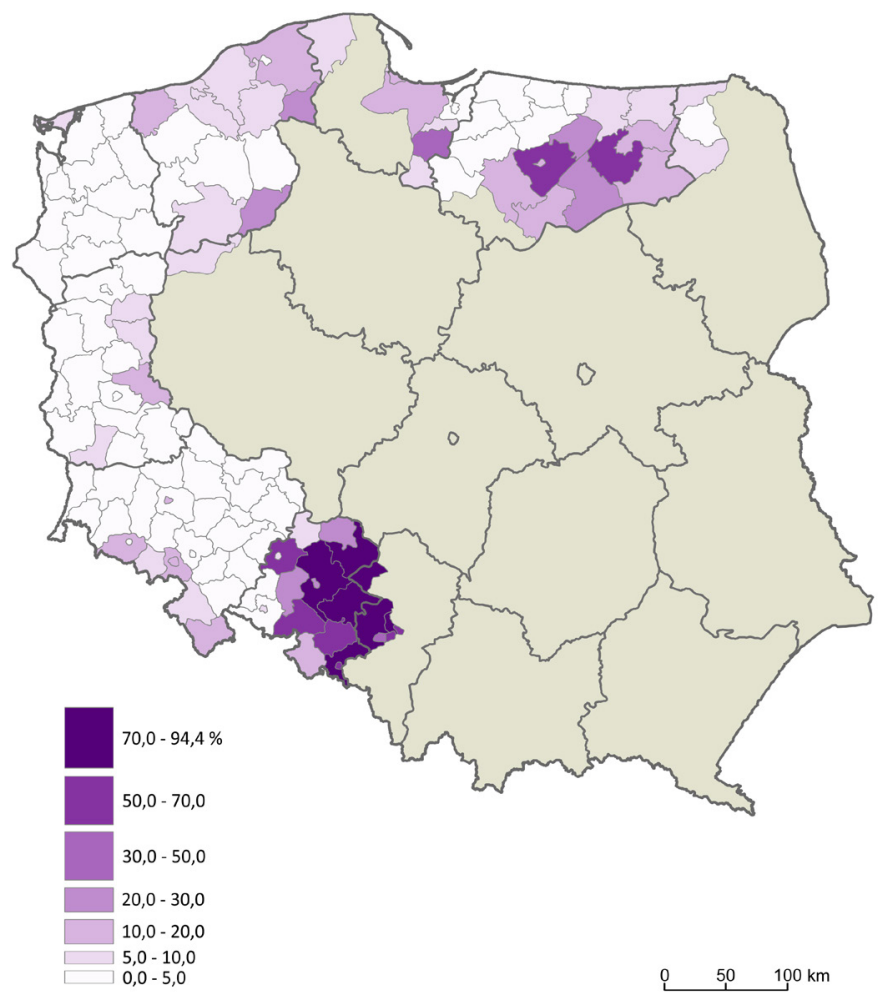

Figure 6. Indigenous population in the Recovered Territories in 1950 Source: Author's map based on Kosiński 1960 


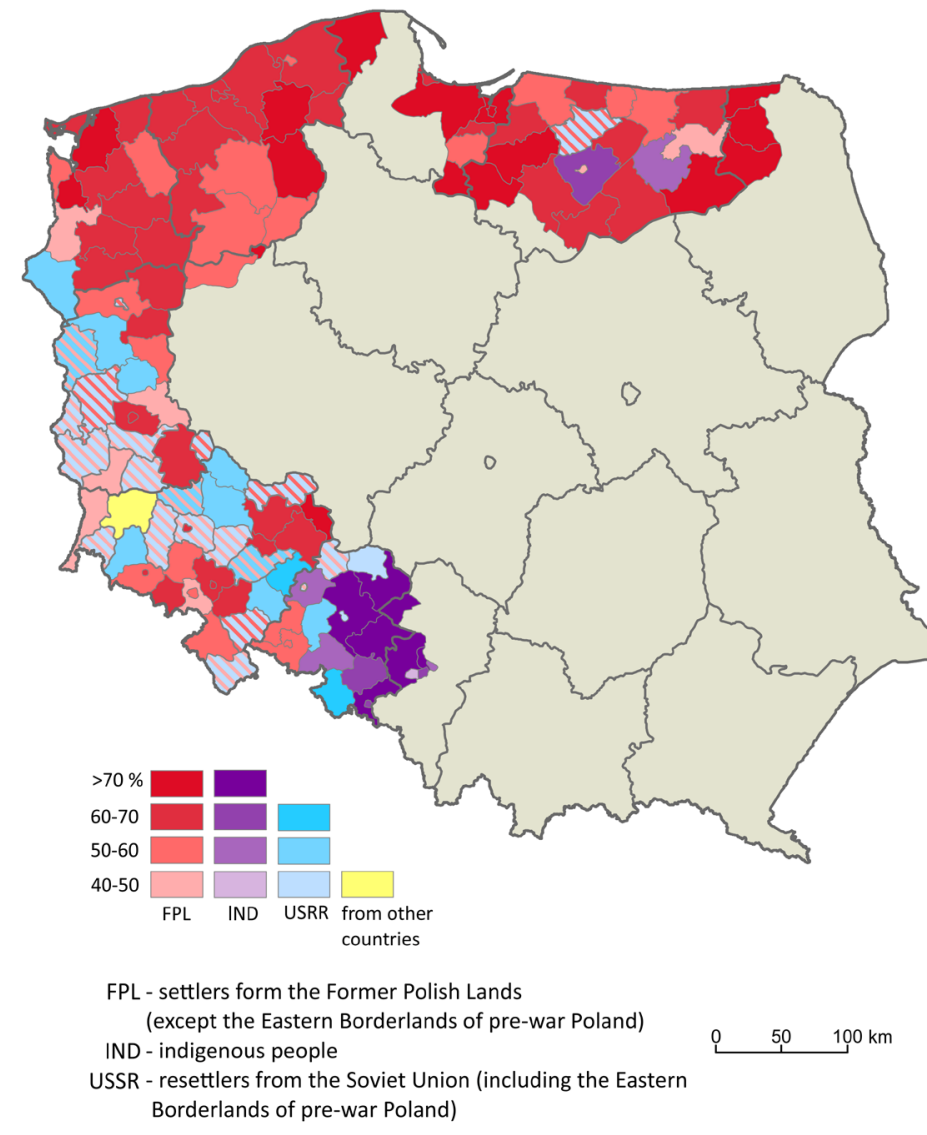

Figure 7. Population of the Recovered Territories by Territorial origin in 1950 Source: Author's map based on Kosiński 1960

research proves that there is still a lot of unprocessed historical data, which would be worth visualizing. Although editing maps has never been as simple as it is now, there are still many aspects of Polish history (even the most recent history), that require comprehensive cartographic study. It is also worthwhile addressing the subject of changing the form and methods of cartographic presentation of existing maps, e.g. sketches, which, apart from being digitally presented, can be enriched with additional assets and new solutions.

\section{ORCID}

Szczepan Cegiełko (1) https://orcid.org/0000-0001-5706-5508 Izabela Karsznia (1D) https://orcid.org/0000-0001-5510-8770

\section{References}

Dekret z dnia 6 października 1948 r. o zmianie granic województwa lubelskiego i województwa warszawskiego [Decree of 6 October 1948 on the change of Lubelskie and Warsaw voivodeships borders], Dz.U. 1948 nr 49 poz. 371. Available from: <http://isap.sejm. gov.pl/isap.nsf/DocDetails. xsp?id=WDU19480490371>. [10 February 2018].

Eberhardt, P 2011, Political migrations on Polish territories (1939- 1950), Instytut Geografii i Przestrzennego Zagospodarowania im. Stanisława Leszczyńskiego PAN, Warszawa.

Freitag, U 1966, 'Verkehrskarten - Systematik Und Methodik der kartographischen Darstellung des Verkehrsmit Beispilen zur Verkehrsgeographie des mittleren Hessen' [Traffic maps - Systematics and methodology of Cartographic representation of the traffic with examples on the transport geography of central Hessen'], Giessener Geographische Schriften, vol. 8, Institut für Geographie der Justus- LiebigUniversität, Giessen.
Gawryszewski, A \& Kosiński, L 1993-1997, 'Pochodzenie terytorialne ludności Ziem Zachodnich i Północnych Polski 1950, 1:4 500 000', Atlas Rzeczypospolitej Polskiej [Territorial origin of the population of Western and Northern Poland 1950, Atlas of the Republic of Poland], vol. 61.3, Główny Geodeta Kraju, Warszawa.

Główny Urząd Statystyczny Polskiej Rzeczypospolitej Ludowej, 1955, Narodowy Spis Powszechny z dnia 3 grudnia 1950 r.: Miejsce zamieszkania ludności w sierpniu 1939 r, [NationalCensus of 3 December 1950.: Place of residence of the population in August 1939], Warszawa.

Guo, D 2009, 'Flow mapping and multivariate visualization of large spatial interaction data', IEEE Transactions on Visualization and Computer Graphics, vol. 15, no. 6. pp.1041-1047.

Harrower, M \& Fabrikant, S 2008, 'The role of map animation for geographic visualisation' in Geographic Visualization: Concepts, Tools and Applications, ed. M Dodge, Wiley, Chichester, pp. 49-57. 
Kałamucki, K \& Buk, D 2010, 'Metodyczne aspekty badania i prezentacji na mapach zmian zjawisk na przykładzie infrastruktury turystycznej Roztoczańskiego Parku Narodowego' ['Methodologicalaspects of research and presentation on maps of change of touristinfrastructure on the example of Roztoczański National Park'], Polski Przegląd Kartograficzny, vol. 43, no. 3, pp. 199-210.

Konieczny, Z 2002, Zmiany demograficzne w Południowowschodniej Polsce w latach 1939-1950 [Demographic changes in south-eastern Poland in 1939-1950], Archiwum Państwowe w Przemyślu, Przemyśl.

Kosiński, L 1960, Dokumentacja Geograficzna: Pochodzenie terytorialne Iudności Ziem Zachodnich w 1950 roku [Geographical documentation: Territorial origin of the population of Western Lands in 1950], Warszawa.

Kosiński, L \& Dziewoński, K 1967, Rozwój i rozmieszczenie ludności w XX wieku [Development and distribution of the population in the 20th century], PWN, Warszawa.

Marcinek, R 1996, Encyklopedia Polski [Encyclopedia of Poland], Kluszczyński, Kraków.

Medyńska-Gulij, B 2015, Kartografia: Zasady i zastosowania geowizualizacji [Cartography: Principles and applications of geo-visualisation], WN PWN, Warszawa.

Meksuła, M 2002, 'Kartograficzna prezentacja dynamiki zjawisk' in Świat mapy - Świat na mapie. Główne problemy współczesnej kartografii [,Cartographic presentation of the dynamics of phenomena'. World of the map - World on the map. Main problems of the modern cartography], ed. W Pawlak, Uniwersytet Wrocławski, Wrocław, pp. 122-136.

Meksuła, M 2001, 'Kartograficzne sposoby prezentowania dynamiki zjawisk' ['Cartographic presentation methods of dynamic phenomena'], Polski Przegląd Kartograficzny, vol. 33, no. 4, pp. 328-338.

ONTOHGIS ontological foundations for building historical geoinformation system 2020. Available from: <https:// ontohgis.pl/przykladowa-strona/ontohgis/>. $\quad[10$ October 2017].

ONTOHGIS ontological foundations for building historical geoinformation system 2020, Mosaic. Available from: <https://ontohgis.pl/przykladowa-strona/ontohgis/http:/ censusmosaic.org/data/historical-gis-files>. [10 October 2017].

Ostrowski, W 1984, 'Próba klasyfikacji metod kartograficznych' ['Anattempt to classify cartographic methods'] in Teoretyczne i Metodyczne Problemy Współczesnej Kartografii, [Theoretical and Methodical Problems of Contemporary Cartography], ed. S Gurba, Lublin, vol. 10, pp. 98-105.

Rozporządzenie Rady Ministrów z dnia 29 maja 1946 r. w sprawie tymczasowego podziału administracyjnego Ziem Odzyskanych [Regulation of the Council of Ministers of 29 May 1946 on the temporary administrative division of the Recovered Territories], Dz.U. $1946 \mathrm{nr} 28$ poz. 177. Available from: <http://isap.sejm.gov.pl/isap.nsf/DocDetails. xsp?id=WDU19460280177>. [10 February 2018].

Rozporządzenie Rady Ministrów z dnia 21 czerwca 1950 r. w sprawie utworzenia powiatów miejskich z miast: Zielona Góra w województwie poznańskim, Rzeszów w województwie rzeszowskim i Koszalin w województwie szczecińskim [Ordinance of the Council of Ministers of 21 June 1950 on the establishment of city poviats from the cities of Zielona Góra in the Province of Poznań, Rzeszów in the Province of Rzeszów and Koszalin in the Szczecin Province], Dz.U. 1950 nr 28 poz. 260. Available from: <http://isap.sejm. gov. pl/isap.nsf/DocDetails.xsp?id=WDU19500280260>. [10 February 20180.
Rozporządzenie Rady Ministrów z dnia 14 grudnia 1950 r. w sprawie zmiany granic powiatów babimorskiego, świebodzińskiego i zielonogórskiego oraz zmiany nazwy powiatu babimorskiego [Regulation of the Council of Ministers of 14 December 1950 on the change of the Babimorski, Świebodziński and Zielona Góra counties' borders and name changes of the district of Babimorsk], Dz.U. 1950 nr 57 poz. 510.

Saliszczew, KA 1984, Kartografia Ogólna [General cartography], PWN, Warszawa.

Ustawa z dnia 28 czerwca 1950 r. o zmianach podziału administracyjnego Państwa [Act of 28 June 1950 on changes in the administrative division of the State], Dz.U. $1950 \mathrm{nr} 28$ poz. 255. Available from . [10 February 2018].

Ustawa z dnia 28 czerwca 1950 r. o zmianach podziału administracyjnego Państwa [Act of 28 June 1950 on the changes in the division of the administrative State], Dz.U. 1950 nr 28 poz. 255. Available from: <http://isap.sejm.gov. pl/isap.nsf/DocDetails. $\quad x s p ? i d=W D U 19500280255>$. [10 February 2018]. 